\title{
PENGEMBANGAN VIDEO PEMBELAJARAN MATEMATIKA UNTUK MENINGKATKAN HASIL BELAJAR KOGNITIF SISWA
}

\author{
Luluk Anisatul Farida $^{1}$, Sri Hariyani ${ }^{2}$, Trija Fayeldi ${ }^{3}$ \\ ${ }^{1,2}$ Program Studi Pendidikan Matematika, Universitas PGRI Kanjuruhan Malang \\ Email: lulukanisa3007@gmail.com
}

\begin{abstract}
Abstrak:
Tujuan penelitian ini yaitu menghasilkan video pembelajaran yang valid, praktis, dan efektif yang dapat meningkatkan hasil belajar kognitif siswa kelas VIII SMP Negeri 5 Malang pada materi Volume Prisma dan Limas. Model pengembangan yang digunakan yaitu ADDIE (analysis, design, development, implementation, and evaluation). Kualitas video pembelajaran yang dihasilkan memenuhi kriteria: a) valid, dengan rata-rata skor penilaian oleh ahli materi dan ahli media sebesar 3,38; b) praktis, dengan rata-rata skor penilaian angket respon guru dan angket respon siswa sebesar 3,50; c) efektif, dengan skor rata-rata hasil tes belajar siswa sebesar 83,75 dan sudah memenuhi Kriteria Ketuntasan Minimal (KKM) di SMP Negeri 5 Malang yaitu 78. Dengan demikian dapat disimpulkan bahwa video pembelajaran yang dikembangkan valid, praktis, dan efektif untuk meningkatkan hasil belajar kognitif siswa kelas VIII SMP Negeri 5 Malang pada materi volume prisma dan limas.
\end{abstract}

Kata Kunci: Video Pembelajaran, Hasil Belajar, Kognitif

\begin{abstract}
:
The purpose of this study is to produce a valid, practical, and effective learning video that can improve cognitive learning outcomes for grade VIII students of Public Junior High School 5 Malang on the Prism dan Pyramid Volume material. The development model used is ADDIE (analysis, design, development, implementation, and evaluation). The quality of the resulting learning video meets the following criteria: a) valid, with an averange score of 3,38 by material experts and media experts; b) practical, with an averange score of teacher response questionnaires and student response questionnaires of 3,$50 ;$ c) effective, with an averange score of student learning test results of 83,75 and has met the Minimum Completeness Criteria (KKM) at Public Junior High School 5 Malang, namely 78. Thus, it can be conclude that the learning videos developed are valid, practical, and effective to improve cognitive learning outcomes of grade VIII Students of Public Junior High School 5 Malang on prism and pyramid volume material.
\end{abstract}

Keywords: Learning Videos, Learning Outcomes, Cognitive.

\section{Pendahuluan}

Media pembelajaran merupakan sesuatu yang dapat membantu proses penyampaian informasi kepada siswa dan merupakan salah satu faktor yang mendukung keberhasilan pembelajaran di sekolah contohnya yaitu buku, video, foto, komputer bahkan televisi (Khairani \& Febrinal, 2016). Pada masa pendemi Covid19, sebagian besar sekolah di Indonesia melaksanakan pembelajaran daring untuk tetap melanjutkan pendidikan. Pembelajaran daring merupakan pembelajaran yang memanfaatkan jaringan internet untuk belajar bagi penggunanya (Elianur, 2020). Pembelajaran daring dapat menggunakan berbagai aplikasi pada Handphone misalnya aplikasi WhatsApp, Zoom Meeting, Google Meet, dan lain-lain. Selain aplikasi, guru dapat menggunakan media pembelajaran berupa video agar tujuan pembelajaran dapat tercapai.

Video pembelajaran tepat digunakan dalam pembelajaran di kelas karena kondisi siswa yang sudah terbiasa dengan perkembangan teknologi jaman sekarang. Video pembelajaran cocok digunakan dalam proses pembelajaran daring maupun luring karena memiliki berbagai kelebihan. Kelebihan video pembelajaran menurut Busyaeri $d k k$ (2016:129) yaitu dapat mengatasi jarak dan 
waktu, dapat diputar berulang kali, memperjelas sesuatu yang abstrak menjadi lebih realistik. Video juga dapat membuat kualitas pembelajaran menjadi lebih menarik dan meningkatkan hasil belajar siswa (Aqib, 2013:51).

Hasil belajar berfungsi sebagai tolak ukur keberhasilan dalam proses pembelajaran dan memiliki tiga indikator yaitu ranah kognitif, afektif, dan psikomotorik. Ranah kognitif yaitu segala sesuatu yang berhubungan dengan otak yang dapat diukur salah satunya dengan tes hasil belajar siswa untuk menunjukkan tingkat kemampuan siswa dalam mencapai tujuan pembelajaran. Oleh karena itu, untuk meningkatkan kemampuan dan kualitas hasil belajar siswa, penting bagi guru menggunakan media pembelajaran salah satunya dengan video sebagai alat untuk berkomunikasi dengan siswa (Hartanti, $d k k$, 2020).

Hasil observasi yang dilakukan di SMP Negeri 5 Malang kelas VIII B-4 menunjukkan bahwa media pembelajaran yang digunakan guru pada pembelajaran masa pandemi Covid-19 adalah Power Point Text yang diberikan saat melakukan Google Meet dengan siswa. Observasi dilakukan dengan pengamatan selama proses pembelajaran di SMP Negeri 5 Malang. Hasil belajar siswa yang dilihat dari tugas-tugas dan ulangan harian menunjukkan bahwa 46,2\% dari 31 siswa belum mencapai Kriteria Ketuntasan Minimal (KKM) di sekolah dan 53,8\% sudah mencapai KKM. Permasalahan yang ditemui pada media pembelajaran yang digunakan adalah terbatasnya siswa dalam mengakses media pembelajaran yang diberikan, karena jika terdapat siswa yang terlambat mengikuti pembelajaran di Google Meet maka siswa tersebut akan tertinggal untuk mendengarkan penjelasan dari Power Point Text yang diberikan guru.

Penelitian terdahulu tentang pengembangan video pembelajaran pernah dilakukan sebelumnya oleh Meryansuamyeka, Yusuf, dan Suganda (2018). Dalam penelitian tersebut mengembangkan video pembelajaran berbasis PMRI (Pendekatan Matematika Realistik Indonesia) untuk melatih mental calculation siswa dalam permasalahan aritmatika sosial. Hasil penelitian menunjukkan bahwa video pembelajaran yang dikembangkan sudah sesuai dengan tipe belajar siswa hanya perlu diperhatikan bahwa video harus mengarah pada rencana pelaksanaan pembelajaran. Video pembelajaran dinyatakan valid oleh para ahli yang menguji 2 aspek yaitu aspek materi dan tampilan media, dinyatakan praktis berdasarkan hasil penelitian pada skala satu-satu yaitu mengujicobakan produk pada 3 siswa kelas VII SMP Islam Terpadu Roudhatul Ulum Sakatiga Indralaya yang berkemampuan berbeda dan pada skala kelompok kecil yang berjumlah 6 orang, dilihat dari perbandingan nilai ratarata siswa pada pretest dan posttest yaitu sebesar 67,73 dan skor N-Gainnya diperoleh skor 0,35 video pembelajaran yang dikembangkan memiliki efek potensial untuk mendukung mental calculation siswa dalam permasalahan aritmatika sosial. Berbeda dengan penelitian sebelumnya, peneliti mengembangan video pembelajaran yang dapat meningkatkan hasil belajar kognitif siswa dan video pembelajaran yang dikembangkan mengarah pada rencana pelaksanaan pembelajaran agar tujuan pembelajaran dapat tercapai.

Berdasarkan permasalahan yang telah dipaparkan maka diperlukan pengembangan media pembelajaran berupa video pembelajaran matematika yang dapat digunakan guru dalam meningkatkan hasil belajar dalam ranah kognitif. Peneliti memilih untuk mengembangkan video pembelajaran karena dapat mengatasi keterbatasan ruang dan waktu serta mudah diakses oleh siswa pada saat pembelajaran masa pandemi saat ini. Video pembelajaran yang dikembangkan berisi konsep dasar materi, animasi gambar bergerak, contoh gambar yang berhubungan dengan materi, dan beberapa tips dalam menyelesaikan permasalahan yang terdapat dalam materi. Peneliti mengambil materi kelas VIII yaitu Volume Prisma dan Limas karena materi tersebut perlu divisualisasikan dalam bentuk gambar maupun video untuk memudahkan pemahaman siswa. 


\begin{abstract}
Pentingnya penelitian pengembangan video pembelajaran matematika ini bagi guru yaitu dapat memberikan gambaran tentang video pembelajaran matematika dan video pembelajaran matematika yang dihasilkan dapat digunakan sebagai sumber belajar bagi siswa SMP Negeri 5 Malang. Sedangkan bagi sekolah dapat memberikan kontribusi yang baik dalam meningkatkan kualitas pembelajaran matematika di sekolah serta penggunaan video pada proses pembelajaran dapat membantu memberikan solusi bagi sekolah pada saat pembelajaran masa pandemi Covid-19.
\end{abstract}

\section{Metode Penelitian}

Jenis penelitian yang digunakan dalam penelitian ini yaitu penelitian pengembangan atau Research and Development (R\&D). Model pengembangan yang digunakan yaitu ADDIE yang dikembangan oleh Dick and Carry yang berfungsi untuk merancang sistem pembelajaran di kelas (Mulyatiningsih, 2012:184). Model penelitian ini memiliki lima tahap, sebagai berikut: 1) Tahap Analisis (Analysis). Pada tahap analisis dilakukan berdasarkan studi lapangan dan studi pustaka yang terdiri atas analisis kompetensi, analisis kondisi siswa, dan analisis materi; 2) Tahap Desain/Perancangan (Design). Pada tahap perancangan dilakukan kegiatan penyusunan instrumen penelitian, penyusunan kerangka video pembelajaran, penyusunan sistematika video pembelajaran; 3) Tahap Pengembangan (Development). Pada tahap ini dilakukan pembuatan video pembelajaran menggunakan aplikasi Filmora sesuai rancangan yang telah disusun. Video pembelajaran yang telah dibuat kemudian divalidasi oleh ahli media dan ahli materi untuk mengetahui kelayakan video pembelajaran sebelum dilakukan uji coba; 4) Tahap Implementasi (Implementation). Pada tahap ini dilakukan uji coba kepada siswa kelas VIII B SMP Negeri 5 Malang, kemudian dilakukan penilaian angket respon guru dan angket respon siswa serta melakukan tes hasil belajar siswa untuk mendapatkan data kepraktisan dan kefektifan video pembelajaran; 5) Tahap Evaluasi (Evaluation). Pada tahap evaluasi yaitu dilakukan perbaikan video pembelajaran sesuai masukan dari siswa dan guru.

Waktu penelitian dilaksanakan pada hari Kamis, 8 April 2021 dilakukan uji coba terbatas, dan pada hari Selasa, 13 April 2021 dilakukan uji coba lebih luas. Tempat penelitian yaitu di SMP Negeri 5 Malang. Target/sasaran yaitu guru sebagai ahli materi dan siswa kelas VIII SMP Negeri 5 Malang sebagai subjek uji coba. Subjek dalam penelitian ini adalah siswa kelas VIII SMP Negeri 5 Malang, untuk uji coba terbatas dengan sampel yang berjumlah 6 siswa kelas VIII B yang dipilih secara acak dan uji coba lebih luas dengan sampel 31 siswa kelas VIII B.

Instrumen pengumpulan data dalam penelitian ini dibagi menjadi tiga yaitu: 1) Instrumen untuk mengukur kevalidan video pembelajaran. Instrumen penilaian ini yaitu lembar validasi berupa angket yang diberikan kepada ahli media dan ahli materi. Instrumen untuk ahli media mencakup pernyataan mengenai aspek kualitas media, aspek penggunaan bahasa, dan aspek tampilan media. Instrumen untuk ahli materi mencakup pernyataan mengenai aspek isi, aspek bahasa, dan aspek penyajian; 2) Instrumen untuk mengukur kepraktisan video pembelajaran. Intrumen penilaian ini yaitu berupa lembar angket respon guru dan angket respon siswa yang memuat beberapa pernyataan mengenai aspek bahasa, aspek materi, aspek tampilan, aspek pengoperasian, dan aspek kemanfaatan; 3) Instrumen untuk mengukur keefektifan video pembelajaran. Intrumen ini berupa tes hasil belajar siswa yang digunakan untuk mengetahui tingkat pemahaman siswa tentang materi volume prisma dan limas setelah mengikuti pembelajaran menggunakan video pembelajaran yang dikembangkan. Selain itu, tes ini juga untuk mengukur hasil belajar kognitif siswa yang sesuai dengan tujuan dikembangkannya video pembelajaran. Data yang diperoleh dari hasil tes belajar digunakan untuk mengetahui kualitas video pembelajaran 
ditinjau dari aspek keefektifan. Soal yang diberikan dalam tes ini yaitu soal esai.

Teknik analisis data dalam penelitian ini dibagi menjadi dua yaitu: 1) Analisis data kualitatif diperoleh dari masukan validator, guru, siswa, dan catatan selama uji coba. Data tersebut dianalisis kemudian digunakan untuk pertimbangan perbaikan video pembelajaran; 2) Analisis data kuantitatif yaitu: a) Data penilaian oleh ahli media dan ahli materi. Dalam proses validasi ahli media dan ahli materi diberikan lembar angket yang berisi beberapa pernyataan dengan skala likert. Masing-masing jawaban yang diperoleh diberi skor dengan kriteria pada tabel sebagai berikut:

Tabel 1. Skor Pengisian Angket

\begin{tabular}{cc}
\hline Skor & Kriteria \\
\hline 4 & Sangat baik \\
3 & Baik \\
2 & Cukup \\
1 & Kurang \\
0 & Sangat kurang \\
\hline
\end{tabular}

Analisis perhitungannya adalah :

Nilai $=\frac{\text { jumlah } \text { Skor }}{\text { Jumlah Pernyataan }}$

Setelah diperoleh nilainya, kemudian nilai tersebut diubah kedalam kriteria kuantitatif dengan pedoman sebagai berikut:

Tabel 2. Kriteria Validitas

\begin{tabular}{cc}
\hline Nilai & Kriteria \\
\hline $3,20<$ Nilai $\leq 4,00$ & Sangat baik \\
$2,40<$ Nilai $\leq 3,20$ & Baik \\
$1,60<$ Nilai $\leq 2,40$ & Cukup \\
$0,80<$ Nilai $\leq 1,60$ & Kurang \\
$0,00<$ Nilai $\leq 0,80$ & Sangat kurang \\
\hline
\end{tabular}

Ario \& Asra, 2019:24

Video pembelajaran dinyatakan valid jika rata-rata hasil penilaian dari ahli media dan ahli materi masuk pada kriteria baik atau sangat baik.

b) Data angket respon guru dan angket respon siswa. Langkah-langkah penilaian angket respon guru dan respon siswa sama dengan penilaian validasi ahli media dan ahli materi. Dengan menggunakan pedoman tabel 1 dan tabel 2 maka dapat ditentukan kualitas video pembelajaran dari segi kepraktisannya berdasarkan angket respon guru dan angket respon siswa. Video pembelajaran dinyatakan praktis jika ratarata penilaian pada angket respon guru dan penilaian pada angket respon siswa memperoleh kriteria baik atau sangat baik; c) Data tes hasil belajar. Setelah diperoleh data nilai tes hasil belajar, selanjutnya data tersebut dicari rata-ratanya dengan menggunakan rumus:

$$
\bar{X}=\frac{\sum X}{n}
$$

Keterangan:

$\overline{\bar{X}}=$ rata-rata perolehan nilai

$\sum X=$ jumlah nilai yang diperoleh

$n=$ banyaknya siswa

Setelah diperoleh rata-rata nilai tes hasil belajar, kemudian nilai tersebut diubah ke dalam kriteria kuantitatif dengan pedoman sebagai berikut:

\section{Tabel 3. Kriteria Efektifitas}

\begin{tabular}{cc}
\hline Rentang & Kriteria \\
\hline $80 \leq \bar{X} \leq 100$ & Sangat baik \\
$65 \leq \bar{X}<80$ & Baik \\
$55 \leq \bar{X}<65$ & Cukup \\
$45 \leq \bar{X}<55$ & Kurang \\
$0 \leq \bar{X}<45$ & Sangat kurang \\
\hline
\end{tabular}

Ario \& Asra, 2019:24

Video pembelajaran dinyatakan efektif jika rata-rata tes hasil belajar siswa memperoleh kriteria baik atau sangat baik.

\section{Hasil dan Pembahasan \\ Hasil}

Tahap Analisis (Analysis) dilakukan berdasarkan studi lapangan dan studi pusaka yang terdiri atas analisis kompetensi, analisis kondisi siswa, dan analisis materi. a) Analisis Kompetensi. Analisis kompetensi meliputi analisis kompetensi dasar dan indikator pencapaian kompetensi yang disajikan pada Tabel 3 sebagai berikut: 
Tabel 4. Hasil Analisis Kompetensi Dasar dan Indikator Pencapaian Kompetensi

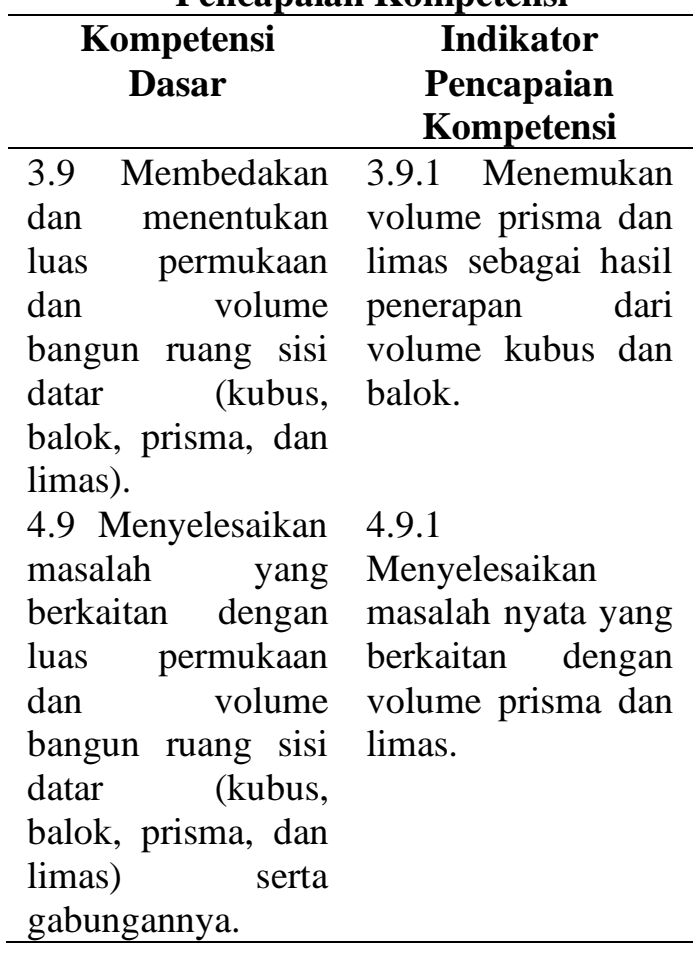

b) Analisis Kondisi Siswa. Dalam menyampaikan pembelajaran pada saat daring, guru menggunakan aplikasi Google Meet. Dalam menyempaikan materi, guru menggunakan Power Point Text, akibatnya jika siswa terlambat hadir atau tidak hadir maka siswa tersebut akan tertinggal dalam menerima materi yang diajarkan pada saat pertemuan Google Meet. Dalam observasi yang dilakukan oleh peneliti, banyak siswa yang terlambat dan tidak hadir dalam pertemuan Google Meet dan sebagian siswa kurang aktif dalam pembelajaran; c) Analisis Materi. Materi yang digunakan dalam penelitian ini adalah materi volume prisma dan limas. Materi ini perlu divisualisasikan misalnya dalam bentuk gambar dan video. Oleh karena itu, video pembelajaran sangat penting agar siswa menjadi lebih mudah dalam menguasai materi volume prisma dan limas.

Tahap Desain/ Perancangan (Design) dilakukan kegiatan sebagai berikut: a) Penyusunan Instrumen Penelitian. Instrumen penelitian terdiri dari lembar validasi ahli media, lembar validasi ahli materi, angket respon guru, angket respon siswa, dan tes hasil belajar siswa. Selanjutnya, instrumen tersebut dikonsultasikan kepada dosen pembimbing. Setelah dosen pembimbing memberikan persetujuan, instrumen tersebut digunakan untuk penelitian; b) Penyususnan Kerangka Video Pembelajaran. Video pembelajaran diedit menggunakan aplikasi Filmora versi 7.5.0. Komponen-komponen pendukung seperti gambar dan background diambil dari Google dan Pinterest. Sedangkan animasi gambar bergerak diambil dari aplikasi Geogebra. Untuk slide teks dan urutan tampilan materi diambil dari Power Point Text. Materi yang digunakan dalam video pembelajaran dibagi menjadi empat pokok bahasan sesuai dengan hasil analisis kompetensi dasar yaitu: Menemukan volume prisma sebagai hasil penerapan dari volume balok, menemukan volume limas sebagai hasil penerapan dari volume kubus, menyelesaikan masalah sehari-hari yang berkaitan dengan volume prisma, menyelesaikan masalah sehari-hari yang berkaitan dengan volume limas; c) Penyusunan Sistematika. Sistematika video pembelajaran matematika disusun berdasarkan Rencana Pelaksanaan Pembelajaran (RPP) yang digunakan oleh guru. Sistematika video pembelajaran yaitu judul, pembuka (salam pembuka dan katakata motivasi), menyampaikan kompetensi dasar dan indikator, apersepsi, contoh dalam kehidupan sehari-hari terkait $m$,ateri pembelajaran, menyampaikan manfaat mempelajari volume prisma dan limas, menyampaikan tujuan pembelajaran, menyampaikan materi, latihan soal, penutup (kesimpulan, tips, kata-kata motivasi, dan salam penutup).

$$
\text { Tahap }
$$

Pengembangan

(Development) dilakukan pembuatan video pembelajaran menggunakan aplikasi Filmora sesuai rancangan yang telah disusun. Berikut ini adalah hasil dari video pembelajaran yang telah dibuat. 


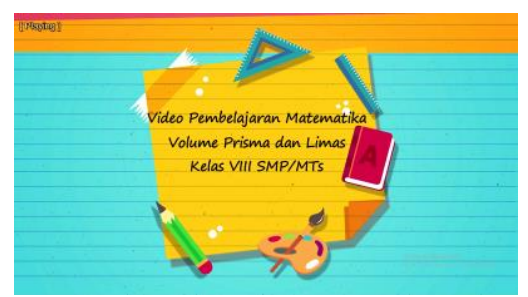

Gambar 1. Tampilan Judul Video Pembelajaran

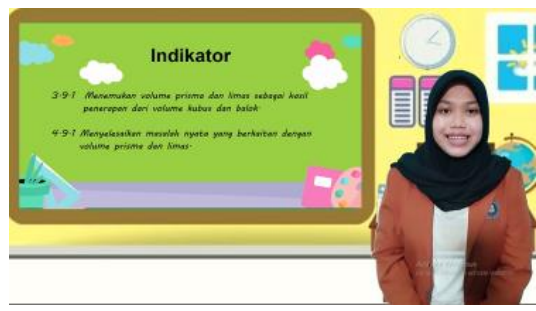

Gambar 2. Penyampaian Kompetensi Dasar

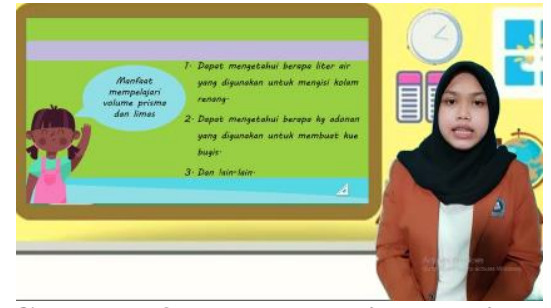

Gambar 3. Penyampaian Indikator

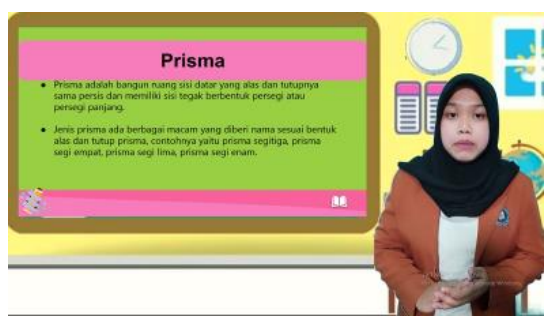

Gambar 4. Penyampaian Apersepsi Tentang Pengertian Prisma

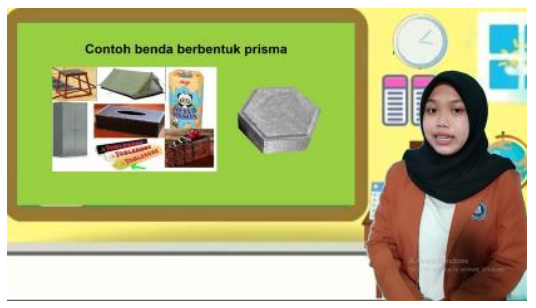

Gambar 5. Penyampaian Contoh Benda Berbentuk Prisma

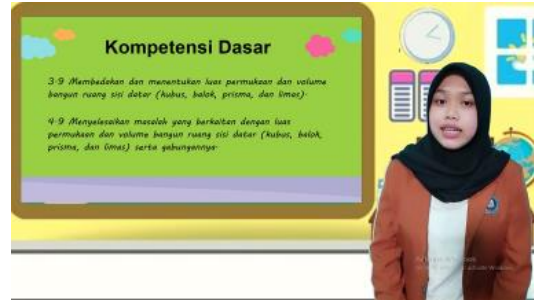

Gambar 6. Penyampaian Manfaat Mempelajari Volume Prisma dan Limas

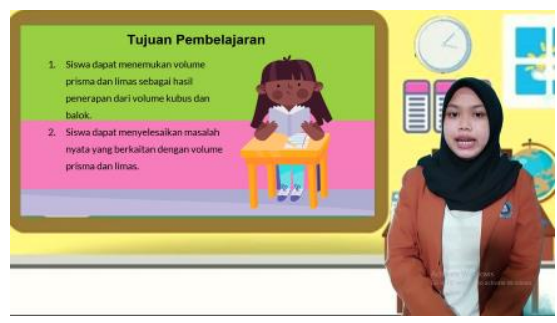

Gambar 7. Penyampaian Tujuan Pembelajaran

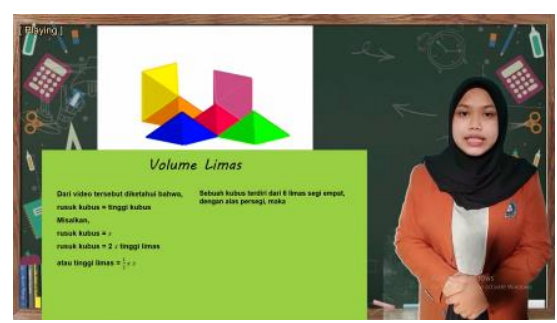

Gambar 8. Peyampaian Materi

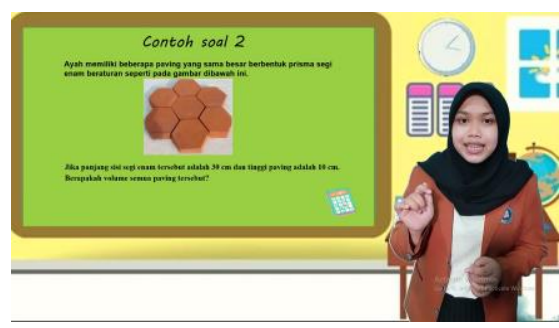

Gambar 9. Penyampaian Contoh Soal

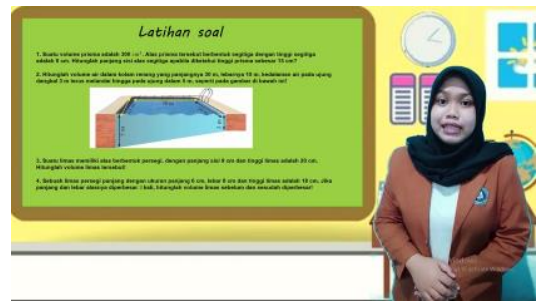

Gambar 10. Penyampaian Latihan Soal 
Setelah video pembelajaran selesai dibuat, kemudian divalidasi oleh ahli media yaitu dosen pendidikan matematika Universitas PGRI Kanjuruhan Malang dan ahli materi yaitu guru matematika SMP Negeri 5 Malang. Hasil validasi disajikan pada tabel berikut ini:

Tabel 5. Hasil Validasi oleh Ahli Media dan Ahli Materi

\begin{tabular}{ccc}
\hline Validator & Nilai & Kriteria \\
\hline Ahli Media & 3,3 & Sangat Baik \\
Ahli Materi & 3,46 & Sangat Baik \\
$\begin{array}{c}\text { Rata-rata } \\
\text { nilai }\end{array}$ & 3,38 & Sangat baik \\
\hline
\end{tabular}

Setelah memperoleh penilaian dan masukan dari para ahli, video pembelajaran direvisi sesuai saran para ahli yaitu background harus lebih cerah dan font diperbesar. Hasil beberapa bagian video pembelajaran sebelum dan sesudah direvisi yaitu:

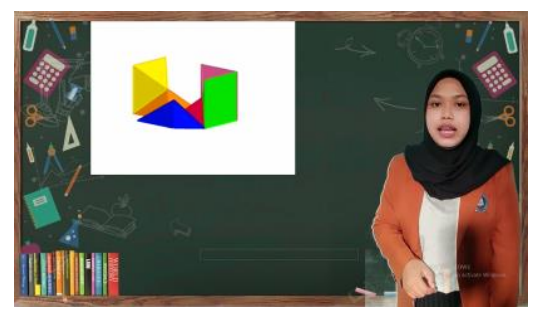

\section{Gambar 11. Tampilan Video Pembelajaran Sebelum Direvisi}

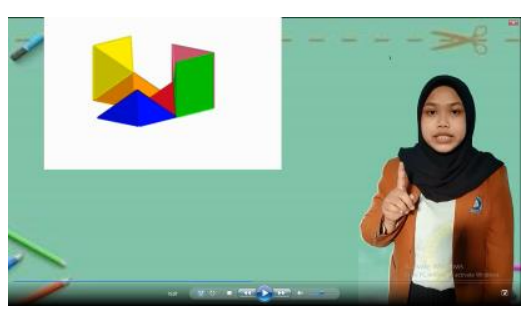

Gambar 12. Tampilan Video Pembelajaran Setelah Direvisi
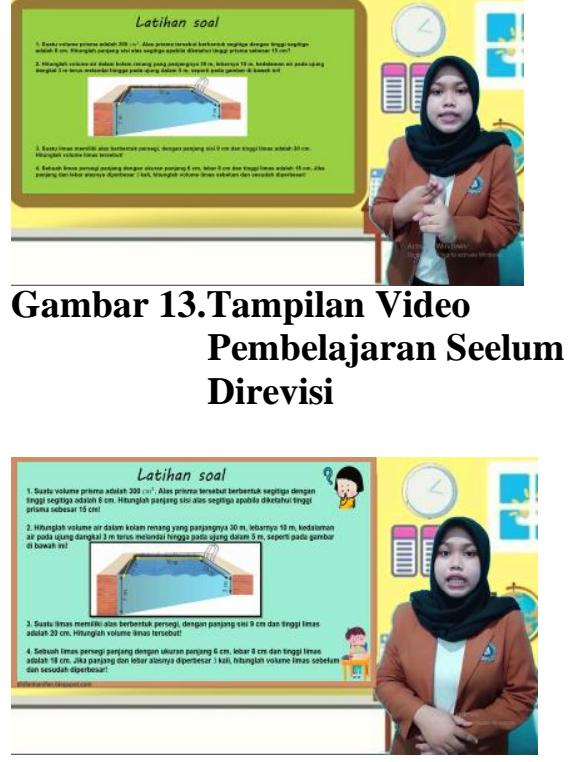

\section{Gambar 14. Tampilan Video Pembelajaran Setelah Direvisi}

Tahap

Implementasi

(Implementation) dilakukan setelah video pembelajaran divalidasi dan diperbaiki, selanjutnya video pembelajaran diujicobakan secara terbatas kepada 6 siswa kelas VIII B pada tanggal 8 April 2021 untuk memperoleh masukan dan komentar siswa tentang video pembelajaran agar dapat direvisi untuk mendapatkan produk video yang layak digunakan untuk proses pembelajaran. Hasil revisi video pembelajaran yaitu background papan tulis diubah menjadi warna biru, font diperbesar, dan pada bagian apersepsi tentang luas bangun datar dan volume kubus dan balok dibuat satu bangun dalam satu slide agar siswa lebih fokus memperhatikan bangun datar yang dibahas :

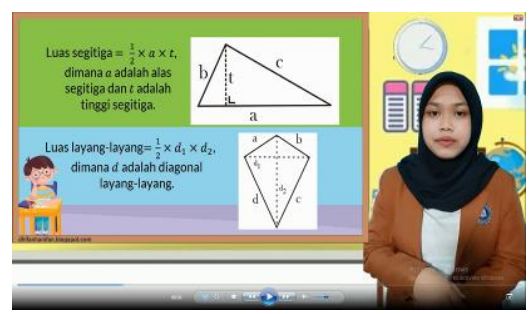

Gambar 15. Tampilan Video Pembelajaran Sebelum Direvisi 


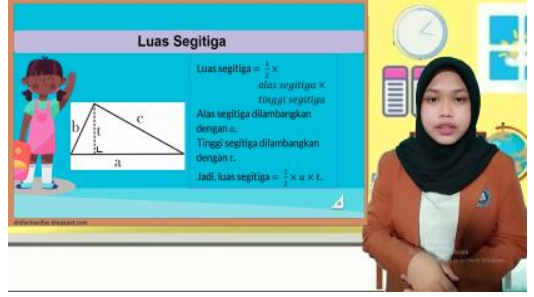

Gambar 16. Tampilan Video Pembelajaran Setelah Direvisi

Selanjutnya video yang telah direvisi diujicobakan pada uji coba lebih luas yaitu pada seluruh siswa kelas VIII B pada tanggal 13 April 2021 yang diikuti oleh 24 siswa. Uji coba lebih luas dilakukan untuk mengetahui seberapa kepraktisan dan keefektifan video pembelajaran yang telah dikembangan. Penilaian kepraktisan produk dilihat dari angket respon guru dan angket respon siswa. Sedangkan keefektifan produk dilihat dari nilai hasil tes belajar siswa. Berikut ini adalah hasil penilaian angket respon guru dan angket respon siswa:

\section{Tabel 6. Hasil Penilaian Angket Respon} Guru dan Angket Respon Siswa

\begin{tabular}{ccc}
\hline Penilai & Nilai & Kriteria \\
\hline Guru & 3,62 & Sangat baik \\
Siswa & 3,39 & Sangat baik \\
Rata-rata & 3,50 & Sangat baik \\
nilai & & \\
\hline
\end{tabular}

Penilaian keefektifan yang dilihat dari hasil tes belajar siswa menunjukkan bahwa 9 dari 24 siswa masih belum mencapai Kriteria Ketuntasan Minimal (KKM) yaitu 78, dengan rata-rata keseluruhan nilai yaitu 83,75 dengan kriteria sangat baik. Oleh karena itu, video pembelajaran yang dikembangkan dinyatakan efektif.

Tahapan Evaluasi (Evaluation) dilakukan setelah uji coba untuk mengetahui kelebihan dan kelemahan video sebagai perbaikan. Video pembelajaran ini memiliki beberapa kelebihan yaitu tampilan video menarik.dilengkapi dengan animasi, siswa dapat mengakses dengan mudah video pembelajaran di YouTube agar dapat mengulang kembali bagian yang kurang jelas sehigga siswa dapat belajar mandiri, sedangkan kelemahan video pembelajaran yaitu terbatas pada materi volume prisma dan limas.

\section{Pembahasan}

Hasil rata-rata penilaian yang diperoleh dari validator ahli media dan ahli materi terhadap video pembelajaran yang dikembangkan sebesar 3,38 dengan kriteria sangat baik, dapat dikatakan video pembelajaran matematika yang dikembangkan valid untuk diterapkan pada materi volume prisma dan limas. Dalam penelitian yang dilakukan oleh Yanti $d k k$, (2019) menyatakan bahwa tahap validasi ahli media dilakukan untuk mengetahui sejauh mana kelayakan produk yang dikembangkan dilihat dari kualitas video pembelajaran tersebut. Sedangkan validasi ahli materi dilakukan untuk mengetahui apakah materi yang disajikan sudah sesuai dengan kurikulum yang digunakan di sekolah.

Hasil rata-rata penilaian dari angket respon guru dan aangket respon siswa terhadap video pembelajaran yang dikembangkan sebesar 3,50 dengan kriteria sangat baik, dapat dikatakan video pembelajaran matematika praktis untuk dikembangkan. Selain itu, komentar dari guru dan siswa menunjukkan bahwa video pembelajaran yang dikembangkan sangat baik digunakan dalam pembelajaran daring, sangat menarik dan kreatif sehingga dapat menarik minat siswa serta mamudahkan pemahaman siswa. Hal ini sesuai dengan pendapat Anwar \& Wijaya (2020) menyatakan bahwa video pembelajaran dikatakan praktis jika penilaian respon guru dan siswa memiliki presentase yang tinggi serta video yang dikembangkan dapat menarik minat siswa karena adanya rangsangan untuk berfikir sehingga pembelajaran lebih bermakna.

Hasil belajar kognitif dapat diukur salah satunya dengan tes belajar siswa. Berdasarkan hasil tes belajar siswa SMP Negeri 5 Malang Kelas VIII B menunjukkan bahwa rata-rata keseluruhan nilai siswa sebesar 83,75 dengan kriteria sangat baik sehingga video pembelajaran yang dikembangkan dinyatakan efektif. 
Video pembelajaran merupakan salah satu media pembelajaran yang dapat meningkatkan hasil belajar siswa. Hal ini sejalan dengan penelitian yang dilakukan oleh Suryansyah \& Suwarjo (2016) yang menyatakan bahwa video pembelajaran efektif untuk meningkatkan hasil belajar kognitif siswa terbukti dari rata-rata nilai posttest di kelas eksperimen yaitu 82,05 lebih tinggi dibandingkan rata-rata nilai kelas kontrol yaitu 75,53.

Hasil belajar berfungsi sebagai tolak ukur keberhasilan dalam proses pembelajaran dan memiliki tiga indikator yaitu ranah kognitif, afektif dan psikomotorik. Ranah kognitif yaitu segala sesuatu yang berhubungan dengan dengan otak yang yang dapat diukur salah satunya dengan tes hasil belajar siswa. Hasil tes belajar siswa SMP Negeri 5 Malang kelas VIII B menunjukkan bahwa setelah menggunakan video pembelajaran, hasil rata-rata keseluruhan nilai tes belajar siswa adalah 83,75 dan sudah memenuhi Kriteria Ketuntasan Minimal (KKM) yang diterapkan di sekolah yaitu 78. Dengan demikian, video pembelajaran yang dikembangkan berhasil untuk meningkatkan hasil belajar kognitif siswa. Hal ini sejalan dengan pendapat Hartanti, $d k k$. (2020) yang menyatakan bahwa media pembelajaran sangat tepat digunakan pada saat pembelajaran di kelas karena dapat menumbuhkan suasana yang menyenangkan bagi siswa sehingga dapat meningkatkan hasil belajar.

\section{Simpulan dan Saran Simpulan}

Berdasarkan hasil penelitian dapat disimpulkan bahwa kualitas video pembelajaran yang dihasilkan memenuhi kriteria: a) valid, dengan rata-rata skor penilaian oleh ahli media dan ahli materi sebesar 3,38 dengan kriteria sangat baik; b) praktis, dengan rata-rata skor penilaian angket respon guru dan angket respon siswa sebesar 3,50 dengan kriteria sangat baik; c) efektif, dengan skor rata-rata nilai hasil belajar siswa sebesar 83,75 dan sudah memenuhi Kriteria Ketuntasan Minimal (KKM) di SMP Negeri 5 Malang yaitu 78.
Berdasarkan kriteria diatas, video pembelajaran yang dikembangkan dapat dinyatakan valid, prakis dan efektif untuk meningkatkan hasil belajar kognitif siswa kelas VIII SMP Negeri 5 Malang pada materi volume prisma dan limas.

\section{Saran}

Disarankan bagi guru untuk menggunakan video pembelajarans ini sebagai sumber belajar karena sudah memenuhi kriteria valid, praktis, dan efektif serta untuk memberikan pembelajaran yang menyenangkan dan pemahaman yang lebih mudah bagi siswa. Untuk peneliti lain, diharapkan dapat menggunakan aplikasi selain Geogebra untuk membuat tampilan animasi dalam video pembelajaran.

\section{Daftar Pustaka}

Anwar, M., \& Wijaya, M. (2020). Pengembangan Media Pembelajaran Berbasis Video Animasi Dengan Model Pembelajaran Inkuiri Terbimbing Untuk Meningkatkan Hasil Belajar Peserta Didik. 4(1), 3444.

Aqib, Z. (2013). Model-model, Media, dan Strategi Pembelajaran Kontekstual (Inovatif). Bandung: Penerbit Yrama Widya.

Ario, M. \& Asra. (2019). Pengembangan Video Pembelajaran Materi Integral Pada Pembelajaran Flipped Classroom. AKSIOMA: Jurnal Program Studi Pendidikan Matematika, 8(1), 20-31. (Online), https://doi.org/10.24127/ajpm.v8il.17 09, diakses 23 Desember 2020.

Busyaeri, A. Udin, T., \& Zaenudin, A. (2016). Pengaruh Penggunaan Video Pembelajaran Terhadap Peningkatan Hasil Belajar Mapel Ipa di MIN Kroya Cirebon. Al Ibtida: Jurnal Pendidikan Guru MI, 3(1), 116-137. (Online)., https://doi.org/10.24235/al.ibtida.snj. v3il.584, diakses 23 Desember 2020.

Elianur, C. (2020). Pilihan Media Pebelajaran Daring Oleh Guru PAI di 
Bengkulu Tengah. Jurnal As-Salam, 4(1), 37-45. (Online), https://doi.org/10.37249/assalam.v4il.142, diakses 6 Januari 2021.

Hartanti, F. D. Hariyani, S. \& Fayeldi, T. (2020). Pengembangan Media Pembelajaran Matematika Sigeru Buku Pop-Up Berbasis Etnomatematika Materi Kubus dan Balok. Jurnal Pendidikan dan Pembelajaran Matematika, 6 (1), 2230.

Khairani, M. \& Febrinal, D. (2016). Pengembangan Media Pembelajaran Dalam Bentuk Macromedia Flash Materi Tabung untuk SMP Kelas IX.
Jurnal Ipteks Terapan, 10 (2), 95102.

Mulyatiningsih, E. (2012). Riset Terapan Bidang Pendidikan dan Teknik. Yogayakarta: UNY Press.

Suryansyah, T., \& Suwarjo. (2016). Pengembangan Video Pembelajaran Untuk Meningkatkan Motivasi dan Hasil Belajar Kognitif Siswa Kelas IV SD. Jurnal Prima Edukasia. 4, 209-221.

Yanti, Y. A., Buchori, A., \& Nugroho, A. A. (2019). Pengembangan Video Pembelajaran Matematika Melalui Model Pembelajaran Flipped Classroom di Sekolah Menengah Kejuruan. I(6), 381-392. 